\title{
Picoeucaryot alga infecting blue mussel Mytilus edulis in southern Norway
}

\author{
Stein Mortensen ${ }^{1, *}$, Lisbeth S. Harkestad ${ }^{1}$, Rolf-Olav Stene ${ }^{2}$, Tristan Renault $^{3}$ \\ ${ }^{1}$ Institute of Marine Research, PO Box 1870, Nordnes, 5817 Bergen, Norway \\ ${ }^{2}$ County Governor of Vest-Agder, Department of Environment, PO Box 513, 4605 Kristiansand, Norway \\ ${ }^{3}$ IFREMER, Laboratoire de Génétique et Pathologie, 17390 La Tremblade, France
}

\begin{abstract}
During summer 2001, blue mussels Mytilus edulis with abnormal shell growth were collected near Kragerø, southern Norway. The mussels had green spots in their mantle tissues, mainly posteriorly and ventrally, and in the adductor muscle. Mussels from 4 sites had a prevalence of green spots varying from 2 to $71 \%$ that correlated well with shell deformities. Histological examination revealed the presence of round or ovoid algae, 0.9 to $1.5 \times 1.2$ to $2.4 \mu \mathrm{m}$, free within haemocytes and in the lesions, characterised by an inflammatory response and the presence of cellular debris. The alga contain a relatively large nucleus, 1 chloroplast and 1 mitochondrion. Size and morphology suggest that the alga might be a picoeucaryot green alga. Infection of mussel tissues appears to start in the posterior mantle edge, near the siphons, and spread anterior-ventrally in the mantle connective and storage tissues - occasionally spots were also found in the gonad follicles. Large infected areas were also observed in sinuses within the adductor muscle. Only mussels that were 3 yr old or more were infected. Deformations apparently resulted from years of continuous shell formation by a contracted, partly deformed mantle. Most deformed mussels had eroded shells, allowing some light penetration through the exposed, thin nacre. Young, thin-shelled mussels were not infected. The present work suggests that the alga has, at least partially, a parasitic relationship with the mussels, and is associated with pathological alterations in mussel tissues.
\end{abstract}

KEY WORDS: Blue mussel · Mytilus edulis · Picoeucaryot · Algae · Infections · Green pustules · Inflammation $\cdot$ Shell deformities

\section{INTRODUCTION}

The blue mussel Mytilus edulis is a common species along north Atlantic coastlines, often forming dense populations dominating suitable substrates in the littoral zone and in shallow water. It is found along the entire coast of Norway, preferring sheltered and fjord areas that are influenced by brackish water (Hovgaard et al. 2001). Mussels are cultivated, on a limited scale, along most of the Norwegian coastline.

The blue mussel is a highly adaptive species, tolerating a wide range of environmental conditions (Seed \& Suchanek 1992). It appears also to be robust with regard to diseases, as there are worldwide relatively few reported cases of severe disease outbreaks in mussel populations. This might however also reflect the fact that most production areas are self-supplied with spat. The mussel industry does not rely on importation or long distance movements of live mussels, and a natural balance may presumably often exist between host and pathogens. To maintain high production of mussels with low level of losses, both wild mussel beds and cultures should be monitored, and cases of mortalities and abnormalities investigated.

During summer 2001, blue mussels with abnormal shell growth were observed in the area around $\mathrm{Bu}-$ røy, near Kragerø, southern Norway. Affected mussels also had mantle deformities, and green spots in the mantle and adductor muscle. Samples were collected in 2002 and 2003 with the aim of investigating the cause and significance of the observed abnormalities. 


\section{MATERIALS AND METHODS}

Field sampling. Mussels were sampled from 4 sites around Burøy on the island of Skåtøy, and Jomfruland, near Kragerø, southern Norway $\left(58^{\circ} 50^{\prime} \mathrm{N}, 9^{\circ} 35^{\prime} \mathrm{E}\right)$ (Fig. 1) in June 2002 and April 2003. Three samples (1a, $1 \mathrm{~b}$ and 1c) were collected at Site 1, and 1 sample at each of Sites 2, 3 and 4. Each sample consisted of 150 randomly collected mussels, dredged or picked by hand. Sample 1c consisted of empty shells and shell fragments from approximately 300 mussels. Additional mussels were sampled for fixation of affected tissues. Geographical, hydrographical and biological conditions were noted at each sampling site.

Gross morphology. During sampling, 20 mussels were steamed, aircooled, and opened to determine if green spots were apparent after processing. Samples $1 \mathrm{a}, 2,3$ and 4 were subsequently steamed and cooled separately. The length of each mussel shell was measured to the nearest $1 \mathrm{~mm}$. Shell and tissue morphology was categorised as: shell morphology (normal/ deformed); infection site (adductor muscle/mantle edge/gonad area); and infection rate (no/low/moderate/high). Sample 1a had the highest prevalence of infected mussels, and was used for examination of the relationship between infection and shell length. Age of the mussels was estimated using Sample 1b, which was divided into mussel year-classes based on size, shell shape (fast versus slow growing specimens), presumed winter growth rings and erosion and fouling, partly according to Seed (1968). The length of each mussel shell was measured to the nearest $1 \mathrm{~mm}$.
Mussels were steamed and categorised as described above. In addition, the degree of shell deformity (no/low/moderate/high), and infection rate were noted. The prevalence of shell deformities in empty shells and shell fragments was examined in Sample 1c. Shell erosion was examined on 100 visibly eroded shells from Samples 1a, 1b and 4, consisting of mussels that were 2, 3, 4 and 5+ yr old. Mussel tissues were removed, shells were cleaned and dried, observed under a reading lamp (11 W light bulb), and the pattern of light penetration noted. The percentage of infected mussels with shell deformity was calculated from Samples 1a, 2 and 4.

Preparation of samples for light and transmission electron microscopy. For light microscopy, $5 \times 10 \mathrm{~mm}$ samples from tissues with green spots were removed with dissection scissors and observed under a Leica MZ6 stereomicroscope at up to $40 \times$ magnification. Tissue pieces from 20 infected and 10 normal mussels were fixed in Davidson's fixative (Shaw \& Battle 1957), embedded in paraffin, sectioned at $3 \mu \mathrm{m}$ thickness, stained with haematoxylin-eosin and observed under a Leica DMRBE microscope at 100 to $1000 \times$ magnification.

For transmission electron microscopy, mantle fragments collected from live, infected mussels or tissue samples previously placed in Karnowsky's fixative, were fixed in cold $2.5 \%$ glutaraldehyde in $0.2 \mathrm{M}$ cacodylate buffer at $\mathrm{pH} 7.2$ for $1 \mathrm{~h}$. Specimens taken from tissues stored in Karnowsky's fixative were rinsed for $48 \mathrm{~h}$ in $0.2 \mathrm{M}$ cacodylate buffer at $4^{\circ} \mathrm{C}$ before fixation in glutaraldehyde. All samples were then post-fixed in $1 \%$ osmium tetroxide in the same buffer at $4^{\circ} \mathrm{C}$. Speci-

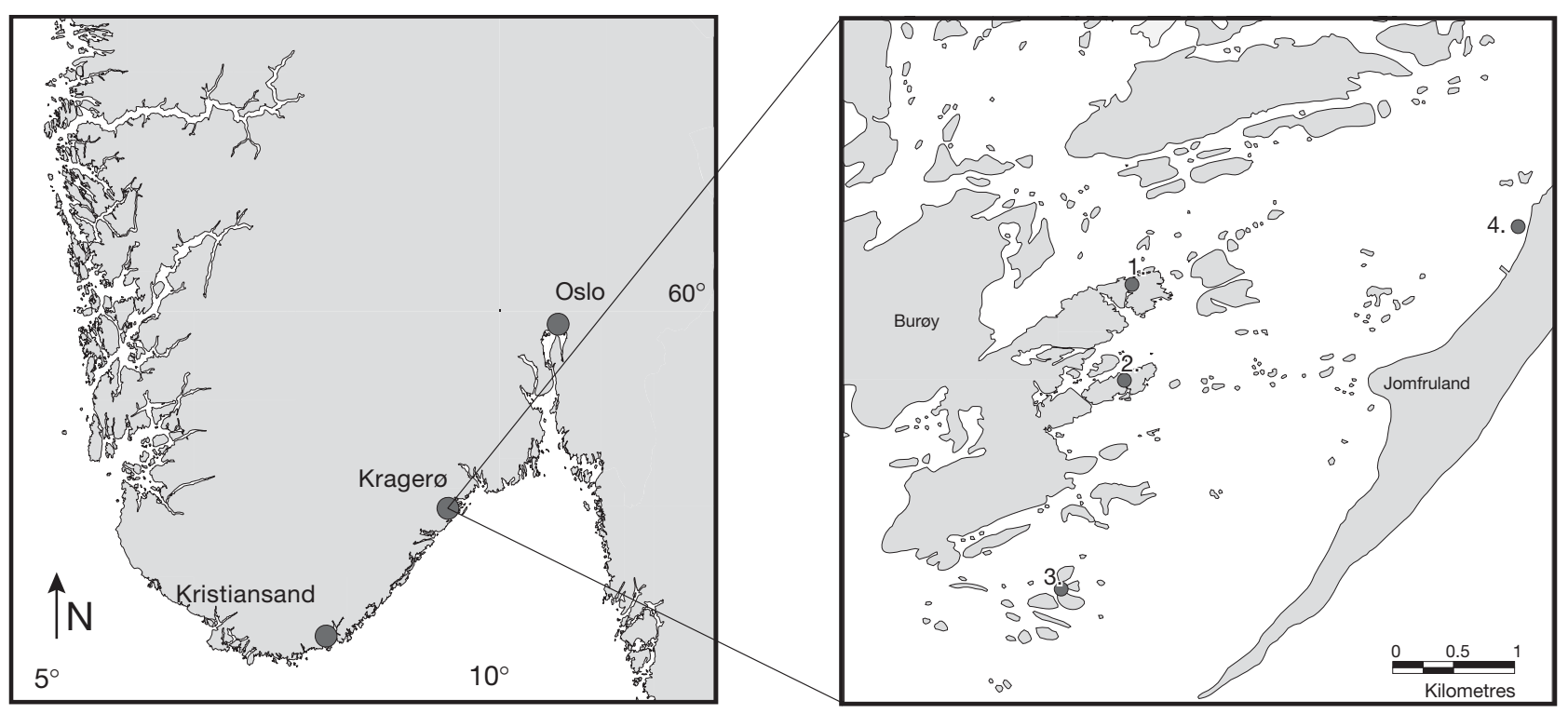

Fig. 1. Southern coast of Norway and archipelago near Kragerø, with positions of islands of Burøy and Jomfruland. 1 to 4 : sampling points 
mens were washed twice in $0.2 \mathrm{M}$ cacodylate buffer, dehydrated in an ascending ethanol series (70 to $100 \%$ ), transferred twice for 15 min to propylene oxide and infiltrated for $1 \mathrm{~h}$ in 50:50 propylene oxide:epon resin. After $1 \mathrm{~h}$ infiltration in pure Epon, they were embedded in resin and cured for $48 \mathrm{~h}$ at $60^{\circ} \mathrm{C}$. Semithin $(1 \mu \mathrm{m})$ sections were stained with $0.5 \%$ toluidine blue in $1 \%$ sodium borate solution. Ultrathin sections were collected on copper grids and double stained with uranyl acetate and lead citrate (Reynolds 1963), and examined in a JEOL JEM 1200 EX transmission electron microscope at $80 \mathrm{kV}$.

Observation under UV light. Green spots from the mantle edge were dissected out and suspended in Keller's medium (Keller et al. 1987). The suspension was examined in UV light at 340 to $380 \mathrm{~nm}$ under a Leitz Aristoplan microscope fitted with a mercury lamp.

\section{RESULTS}

\section{Sample sites}

Mussels were collected from an archipelago with a varied landscape (Fig. 1). The area has relatively large salinity and temperature variations; tidal difference is approximately $30 \mathrm{~cm}$; and tidal currents are weak. Samples $1 \mathrm{a}-\mathrm{c}$ were collected from a sheltered, 2 to $5 \mathrm{~m}$ wide and $8 \mathrm{~m}$ long passage between 2 islands. The depth was 30 to $60 \mathrm{~cm}$, and the mud substrate was covered with random foci of mussel shells and live mussels. Sample 2 was collected from a sheltered, narrow passage, which was dry at the lowest tide. The mud substrate was covered with random foci of mussels. Sample 3 was collected from a more open sound at a depth of 1 to $2 \mathrm{~m}$. The muddy sand substrate was almost covered with mussels. Sample 4 was collected at approximately $30 \mathrm{~cm}$ depth in an open, exposed sound. The sandy substrate was randomly covered with fields of mussels.

\section{Mussel shell morphology and age}

Large, old mussels dominated all samples. Mussels from Sample 1a ranged between 36 to $93 \mathrm{~mm}$, with an average shell length of $71 \mathrm{~mm}$. Mussels from Sample $1 \mathrm{~b}$ ranged between 10 to $93 \mathrm{~mm}$, with an average of $59 \mathrm{~mm}$. Mussels from Sample 2 ranged from 34 to $104 \mathrm{~mm}$, with an average length of $76 \mathrm{~mm}$. Mussels from Sample 3 ranged from 52 to $107 \mathrm{~mm}$, with an average length of $86 \mathrm{~mm}$. Sample 4 ranged from 16 to $84 \mathrm{~mm}$, with an average length of $54 \mathrm{~mm}$. Mussel shells had little fouling, except in Sample 4, where mussels shells were covered with the crustose alga Phyma- tolithon spp. Mussels with deformed shells were found in all samples (Fig. 2). Shells had variable degrees of shell erosion, mainly on the anterior end, and on the thickest parts of the shells. Most eroded shells had lost large parts of the periostracum and calcite layers, exposing portions of the nacre. Deformation occurred up to $30 \mathrm{~mm}$ along the posterior end of the shell. The oldest deformed mussels had a blunt or heart-shaped profile (Fig. 2).

Small deformations were observed at the posterior end of $16 \%$ of the $3 \mathrm{yr}$ old mussels in Sample $1 \mathrm{~b}$ (Fig. 3). Of mussels that were 4 yr or older (more than $71 \mathrm{~mm}$ in length), $42 \%$ had deformed shells. Shell deformities and green spots were correlated; all mussels with deformed shells also had green spots in their posterior mantle tissue. The frequency of infections in adductor muscle and gonad/storage tissues increased with an increasing degree of shell deformity (low/moderate/high) (data not shown). In mussels from Samples $1 \mathrm{a}, 2$ and 3, green spots were observed only in specimens longer than $49 \mathrm{~mm}$ (Fig. 4).

Mussel shells exhibited variable degrees of translucence. All mussel shells in Sample 4 were fouled with
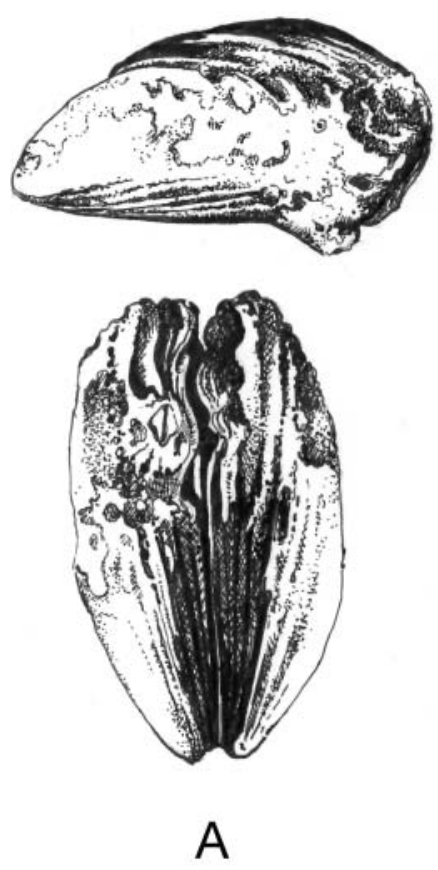
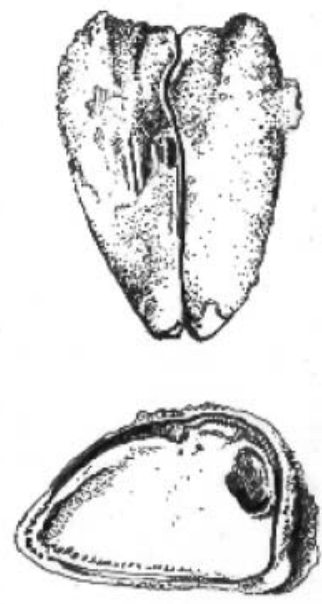

$\mathrm{B}$
Fig. 2. Mytilus edulis. Blue mussels with deformed shells. (A) Mussel from Burøy; mussel was $71 \mathrm{~mm}$ long, at least $5 \mathrm{yr}$ old, with green spots in mantle, gonad, storage tissues and anterior adductor muscle, shell was eroded anteriorly and severely deformed posteriorly; the 2 shell valves did not close properly. (B) Mussel from Sample 4, collected at Jomfruland; mussel was $51 \mathrm{~mm}$ long, had undergone slow growth and was considered to be of same age as Mussel $A_{i}$ degree of infection and shell deformation were also similar to those in Mussel $\mathrm{A}_{\text {; }}$ shell was almost covered with crustose alga Phymatolithon spp. 


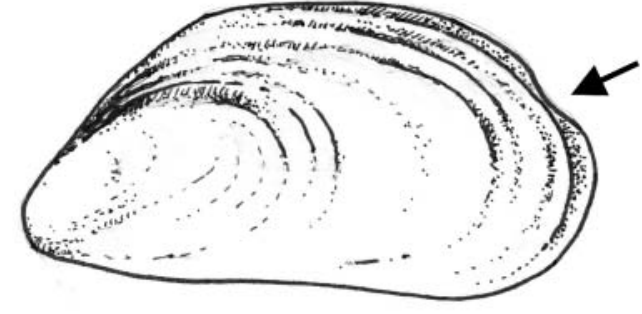

Fig. 3. Mytilus edulis infected by green alga, showing 3 yr old mussel from Sample 1b, with green spots on posterior mantle edge, corresponding to slight deformation in shell margin (arrowed)

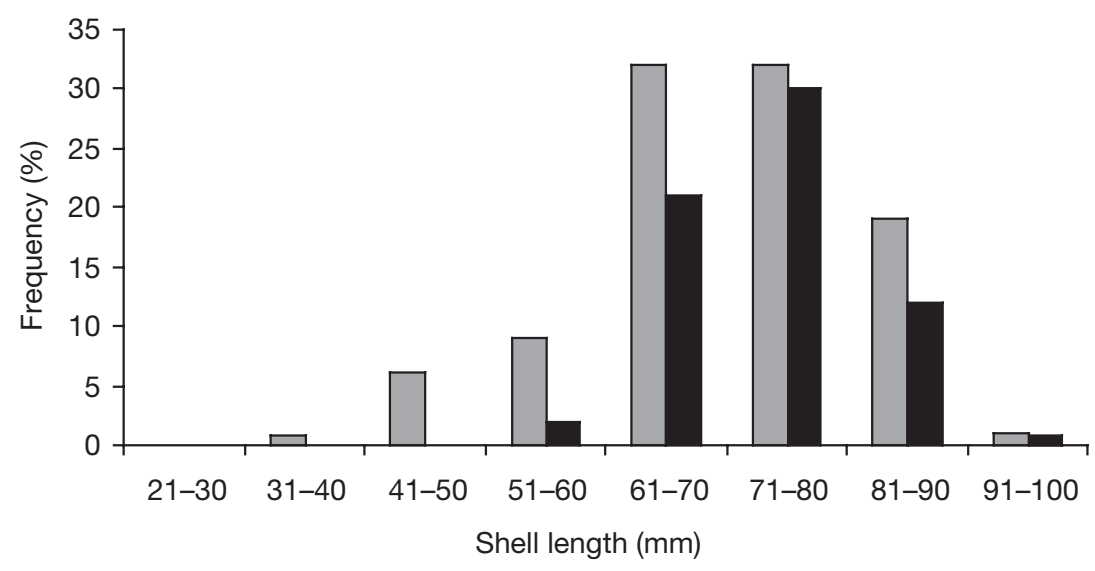

Fig. 4. Mytilus edulis infected by green alga. Frequency (\%) of unaffected mussels (grey columns) and infected mussels (black columns) in Sample 1a as a function of size. $\mathrm{N}=150$

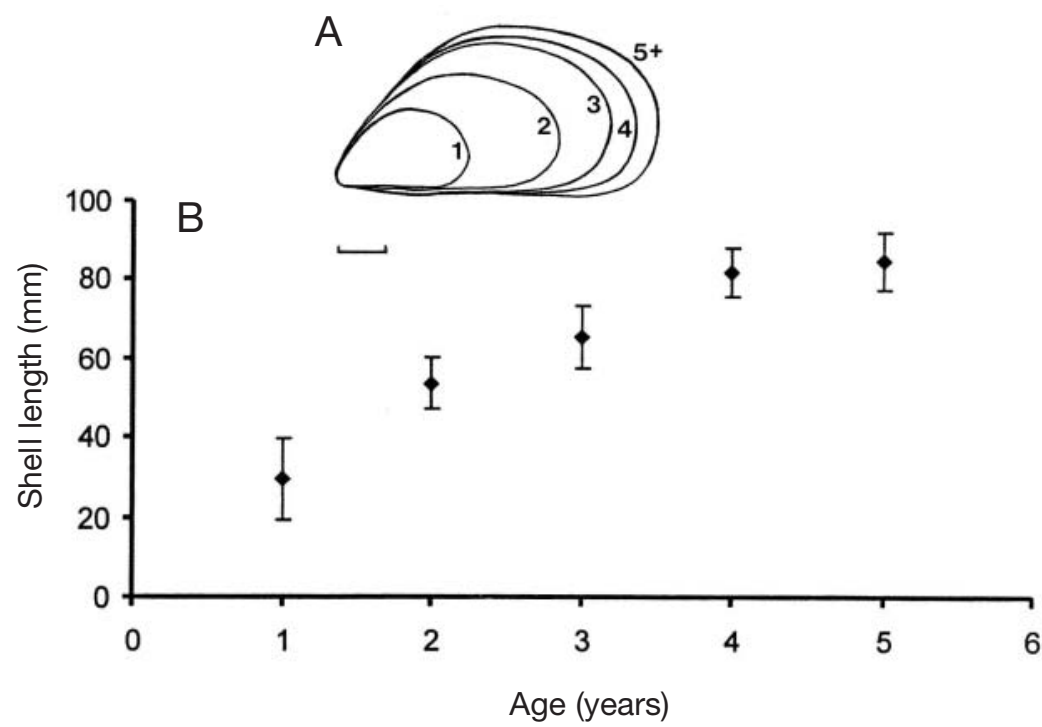

Fig. 5. Mytilus edulis infected by green alga. A: estimated year-rings on mussels that were 1 to $\geq 5 \mathrm{yr}$ old. Scale bar $=10 \mathrm{~mm}$. B: Average $( \pm 1 \mathrm{SD})$ shell length $(\mathrm{mm})$ of 1 to $\geq 5$ yr old mussels in Sample 1b, based upon shell shape, thickness, erosion and fouling crustose algae, and were thus not translucent. Shells from the other samples could be divided into 3 categories: (1) thick shells with low degree of erosion and little or no translucence; (2) relatively thin shells from fastgrowing mussels from all age classes, with a diffuse translucence; (3) shells from 4 yr or older mussels with eroded shells and translucent spots or fields. Heavy shell erosions at the posterior adductor muscle scars of the most severely deformed shells were associated with translucent spots and, in some cases, holes in the shells.

Shells from Sample 1b were divided into 5 yearclasses: 37 mussels were 1 yr old, 27 were 2 year old, 49 were 3 yr old, 14 were four yr old and 11 were 5 yr or older (Fig. 5).

Shells from Sample 1c ranged from 34 to $90 \mathrm{~mm}$ in length. Of 29 recently dead mussels, 14 had deformed shells.

\section{Tissues}

Green spots were clearly visible after steaming, although the colour changed from clear green to a more brownish green. Among 624 mussels in Samples 1a, 2, 3 and 4, 27\% were infected. The prevalence was $71 \%$ in Sample 1a, 2\% in Sample 2, 4\% in Sample 3 and $30 \%$ in Sample 4. Infection rate was graded as:

- No infection (absence of green spots).

- Low infection rate (small, compact green spots, limited to a few areas in mantle edge, posterior adductor muscle may have green spots or areas).

- Moderate infection rate (green spots in larger areas in mantle edge and in gonad area in mantle, posterior adductor muscle has green spots or areas, and appears weakened).

- High infection rate (most of mantle covered with green spots, with mantle edge nearly all green, heavy infection in adductor muscle, with muscle showing clear weakening).

Among affected mussels, 54\% had a low infection rate, $24 \%$ a moderate, and $22 \%$ a high infection rate; 3 tissue areas were affected.

Area 1. Of the infected mussels, $98 \%$ had affected areas in the posterior part of the mantle, near the siphons (Figs. 3 and 6A). Macroscopically, infections were visible as round, clear green spots of different sizes (Fig. 6B). Histologi- 

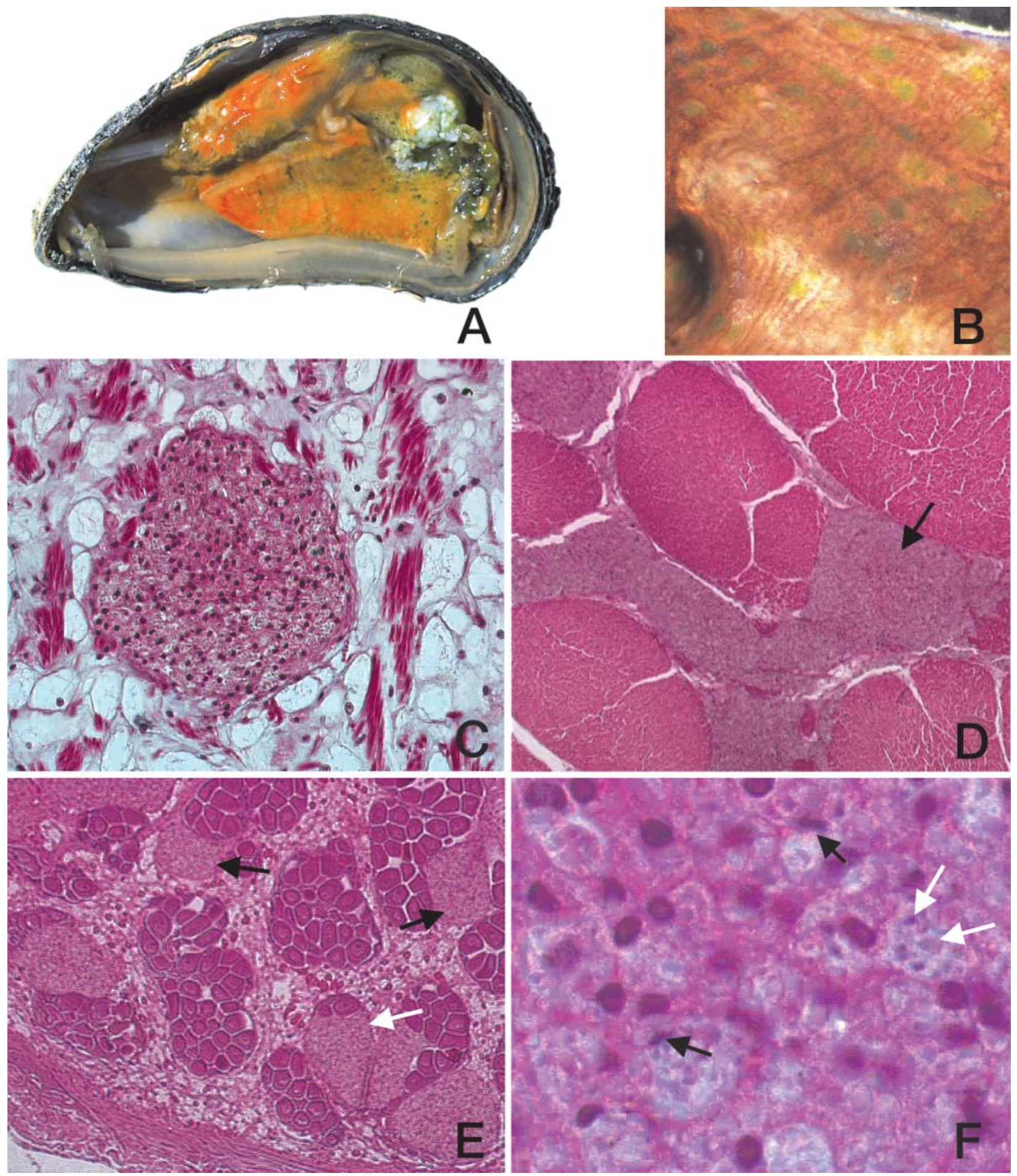

Fig. 6. Mytilus edulis infected by green alga. (A) Mussel from Burøy with green spots in mantle, storage, gonad and adductor muscle tissues and (B) green spots in storage and gonad area of mantle (binocular microscope; $6 \times$ magnification). (C-F) Histological paraffin sections of affected areas in mussel tissues, stained with haematoxylin/eosin: (C) area in muscular part of posterior mantle edge, near siphons; diameter of affected area is approximately $250 \mu \mathrm{m}$. (D) Area in posterior adductor muscle, sinuses between muscle bundles are filled with small foreign cells, haemocytes and cell debris (arrowed). (E) Area in mantle fold, with storage and gonad tissues, green spots are widespread in this area, and appear as distinct areas filled with small foreign cells, haemocytes and cell debris (black arrows), also, some follicles are infected (white arrow). (F) Detail of area in (E); foreign cells are freely present in areas with amorphic, presumably necrotic material (white arrows), as well as inside haemocytes; note haemocytes with phagocytosed cells and peripheral nuclei (black arrows). Original magnifications: $(C) \times 400$, (d) $\times 100,(E) \times 200,(F) \times 1000$ 
cally, these appeared as distinct areas in the muscular part of the mantle margin, packed with haemocytes (Fig. 6C). Haemocytes had surrounded some of the affected areas. Some haemocytes contained a variable number of foreign cells approximately $2 \mu \mathrm{m}$ in size (Fig. 6C,F). Up to 12 cells could be observed in any 1 haemocyte.

Area 2. In addition, $84 \%$ of the infected mussels had green areas in the posterior adductor muscle (Fig. 6A). In contrast to the spots in the mantle, dissection revealed that these areas were liquid. They did not appear to be membrane-bound, and were mainly located between the main muscle bundles. Histologically, the green areas appeared as a continuous mass of cellular debris, haemocytes and numerous foreign cells, which were mainly phagocytosed, but also occurred free (Fig. 6D).

Area 3. Of the mussels with advanced infections, $53 \% \mathrm{had}$, in addition to pustules in the mantle edge and green areas in the adductor muscle, green spots in the gonad and storage-tissue areas of the mantle (Fig. 6A,B). These spots were fairly distinct and of variable size - from very small foci to several millimetres in diameter. They appeared to be similar to those in the posterior part of the mantle. Storage tissue areas, but occasionally also gonad follicles, were mainly infected (Fig. 6E).

\section{Alga size and morphology}

Wet mounts of green spots dissolved in Keller's medium revealed round to ovoid cells, 2-2.5 to $4.5 \mu \mathrm{m}$, emitting red light under UV light, characteristic of chlorophyll, and identifying the cells as alga. Algal cells appeared single or in small aggregations.

Transmission electron microscopy revealed free unicellular organisms in the connective tissues of the mantle of affected mussels (Fig. 7). These organisms possessed a very simple cellular organisation: a relatively large nucleus, a single chloroplast, a mitochondrion, a Golgi body, and very reduced cytoplasm. They were round to ovoid in shape and measured 0.9 to $1.5 \mu \mathrm{m}$ in diameter $(\mathrm{N}=10)$ and 1.2. to $2.4 \mu \mathrm{m}$ in length $(\mathrm{N}=10)$. The cells were also observed within cells interpreted as haemocytes. Also, degenerating unicellular organisms were occasionally found with a pycnotic nucleus and degraded plasma membranes.

\section{DISCUSSION}

The green colour of the mussel soft tissue spots and pustules suggested the presence of a phototrophic organism. Microscopical examination of cells isolated from the green pustules showed cells fluorescing red in UV light, indicating the presence of chlorophyll. The algal nature of the organism was subsequently verified by transmission electron microscopy, which showed that the cells were a unicellular alga (Fig. 7). There are relatively few published reports of similar infections in bivalves. Wiborg (1946) reported Norwegian horse mussels Modiolus modiolus with a green mantle, particularly near the siphons. The green colouration was caused by a small, green flagellate, approximately $12 \mu \mathrm{m}$ in diameter, which was not further described. Naidu \& South (1970) and Naidu (1971) described green mantle-tissues in scallops Placopecten magellanicus from Newfoundland. The green colour was caused by a unicellular, 1.5 to $5 \mu \mathrm{m}$ diameter, round to ovoid alga, living as a parasite in the scallop. The alga was later identified and described as Coccomyxa parasitica by Stevenson \& South (1974).

There are 2 published reports of blue mussels with algae infecting the soft tissues. The first was by Meixner (1984), who examined wild mussels Mytilus edulis with green tissue discolouration from the Flensburg fjord in the Baltic Sea. He described the green spots as colonies of a $3 \times 4 \mu \mathrm{m}$ alga, suggested to be a cyanophyceaen belonging to the genus Microcystis. The

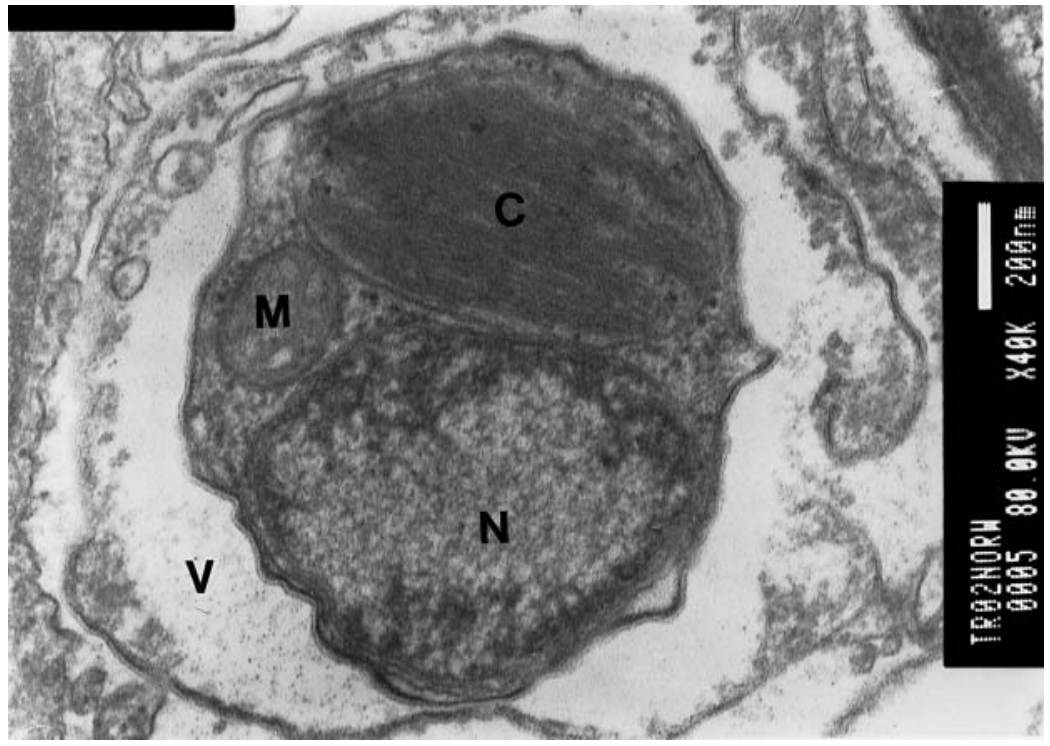

Fig. 7. Transmission electron micrograph from infected area in mussel mantle. Unicellular organisms were detected inside cells in vesicles (V) delimited by a trilamellar membrane in the mantle connective tissue. Cells showed relatively large nucleus $(\mathrm{N})$, chloroplast $(\mathrm{C})$, mitochondrion $(\mathrm{M})$ and reduced cytoplasm containing ribosomes. Scale bar $=200 \mathrm{~nm}$ 
organism was not further described. Later, Gray et al. (1999) found Mytilus edulis chilensis with green spots in their soft tissues in the Falkland Islands. The green spots contained a unicellular, 3 to $11 \mu \mathrm{m}$ diameter alga with 1 or 2 chloroplasts identified as Coccomyxa parasitica.

The alga described in the present study appeared different from the previously described algae from bivalve soft tissues. Measurements under light and electron microscopy (EM) of fixed tissues showed that the alga was smaller than those previously reported. Its small size and low complexity most probably classifies it as a picoplankton. Most algae phyla include some picoeucaryot species, and recently 3 new classes of picoeucaryot algae isolates have been established (Diez et al. 2001). The present picoeucaryot alga therefore cannot be precisely taxonomically positioned based on morphological criteria. EM might provide some information about its taxonomic position, but further studies, including pigment analysis by high performance liquid chromatography (HPLC), flow cytometry or analysis of specific gene sequences are required. On the basis of size, morphology and complexity the algae in the present study might be a picoeucaryot green alga (Chlorophyta) (W. Eikrem pers. comm.).

Sufficient light is a factor crucial to phototrophic algal growth. Bivalve soft-parts should thus be an unfavourable environment for algal growth, unless there is some light penetration through the shell or the alga switches to a heterotrophic or parasitic metabolism after entering the tissues. During filtration, the mantle edge and part of the posterior side of the adductor muscle is exposed to some light. This is in accordance with reports by Wiborg (1946), Stevenson \& South (1974), Meixner (1984) and Gray et al. (1999), and the observation that all infected mussels in the present study had green spots in the posterior part of the mantle. Meixner (1984) showed that only mussels with eroded shells had green spots in the 'flesh' (presumably referring to the gonad and storage tissues). Erosion of the periostracum and calcite layer exposes the thin nacre, and allows light to reach the underlying tissues. Also, Naidu (1971) reported that areas with light penetration were visible when shells from infected scallops were held towards a light source, and related this to the localisation of the infections. In the present study, 2 samples were collected in very shallow water. One of these had an infection prevalence of $2 \%$, the other of $71 \%$. No clear correlation could thus be shown between depth (sunlight exposure) and infection rate. The samples however showed that mussels with the most eroded shells had the most severe deformities and the highest infection rate. The samples also included specimens with translucent shells, which were not infected, such as fast growing, 2 yr old mussels with thin shells. Additionally, Sample 4 contained a high number of infected mussels with shells that were not translucent, due to fouling with crustose algae. Light could therefore not have been the only criterion for algal infection and growth. Preliminary results from algal growth trials (data not shown) indicated however that the alga preferred low light intensity. Overall, the alga may be adapted to growth in low light intensities and an opportunistic, parasitic relationship with the mussels.

Based upon macroscopic observations, the infections apparently caused pathological alterations in mussel tissues. Infections along the mantle edge correspond to mantle contractions and deformations which, over time, led to severe shell deformations resulting from several years of shell deposition with no positive growth in length posteriorly (Figs. 2 \& 3). There also seemed to be a relationship between infections in the posterior adductor muscle, shell erosion in the adductor muscle scar and the ability of the mussels to stay closed. Mussels with severely deformed shells did not close properly, and this may have resulted in a larger opening between the shell halves, more light reaching infected areas, and increased exposure to secondary infections.

There are several possible introductory routes for invading pathogens. One route is through holes or crevices in the shell; however, none of the slightly or moderately infected mussels in the present study displayed damage enabling such invasion. Another route is via the gonadal tubules leading to the mantle cavity; these tubules are ciliated, and an invading organism must enter against the current. Although the follicles of some mussels were infected, microscopic examination of gonad tissues did not reveal the alga in the gonad tubules. A third possibility is entrance through exposed soft tissue epithelia. Naidu (1971) suggested such an introduction route for algae in Placopecten magellanicus, but did not describe the mechanism of penetration. Tripp (1969) showed that the mucus layer covering the exposed visceral body compartments of oysters acts as a physical or chemical barrier for parasites. Stevenson \& South (1975) observed that scallops $P$. magellanicus infected with Coccomyxa parasitica in the mantle had haemocyte aggregations around the algal colonies. Haemocytes phagocytosed the alga, but algal colonies appeared highly resistant to digestion. In the present samples, there was also dense haemocyte infiltration in affected areas. Numerous algal cells were observed inside haemocytes (Fig. 6F) and membrane-bound inside the green pustules. This could indicate a general phagocytic activity when the alga was digested, either through feeding or as part of an immune response, but could also suggest algal multi- 
plication after phagocytosis. Phagocytosed algae may have disseminated via the circulatory system, resulting in systemic infection. The observation of infections in the muscle, where algal cells were not limited to distinct areas (Fig. 6D), supports the hypothesis of such dissemination pattern. Our results suggest an infection point, time and progress. Comparison of shell deformities and degree of infections indicated that the alga apparently first appears on the siphons of approximately 3 yr old mussels, and establishes colonies resulting in green pustules. Pustules, mantle deformities and shell deformities appear first in the posterior part of the mantle. The presence of the alga affects the mantle tissues, leading to contraction, which, over time, results in severe shell deformities. After becoming established in the mantle edge, we propose that the alga spreads via the circulatory system and establishes colonies in the mantle lobes and the haemolymph-filled space in the posterior adductor muscle, where/when some light is available.

The observed changes in infected mussel tissues indicated a strong response, whereby the alga causes inflammation and establishment of areas with necrotic material (Fig. 6). The green spots are pustules, and together with the associated shell deformities, the alterations are pathological. The alga is therefore presumed to have an at least partially parasitic life phase inside the mussel. The rate of infected mussels in each age category indicated that infected mussels did not have a higher mortality rate than non-infected individuals. As shown in Fig. 4, the infection rate increased with increasing age, but the percentage of noninfected mussels did not increase. The present results have thus not demonstrated any increased mortalities in the wild mussel beds as a result of infection by the alga, although infections are likely to weaken infected mussels and make them more susceptible to secondary infections and vulnerable to unfavourable environmental changes.

Acknowledgements. Thanks to I. Hernar, V. Wennevik, L. Årdal, T. Johnsen, E. Lømsland and K. Aursland for technical assistance. Special thanks to B. Chollet for assistance with interpretation of histological sections; to W. Eikrem for valuable discussions concerning algae taxonomy; to A. Duinker for assistance with the age determination of mussels and to $\varnothing$. Bergh for comments on the manuscript. This work was

Editorial responsibility: Albert Sparks, Seattle, Washington, USA financed through funding from the Norwegian Ministry of Fisheries, Institute of Marine Research project 'Bivalve health'.

\section{LITERATURE CITED}

Diez B, Pedros-Alio C, Massana, R (2001) Study of genetic diversity of eukaryotic picoplankton in different oceanic regions by small-subunit rRNA gene cloning and sequencing. Appl Environ Microbiol 67:2932-2941

Gray AP, Lucas IAN, Seed R, Richardson CA (1999) Mytilus edulis chilensis infested with Coccomyxa parasitica (Chlorococcales, Coccomyxaceae). J Molluscan Stud 65:289-294

Hovgaard P, Mortensen S, Strand Ø (2001) Skjell, biologi og dyrking, Kystnæringen Forlag og Bokklubb, Bergen (in Norwegian)

Keller MD, Selvin RC, Claus W, Guillard RRL (1987) Media for the culture of oceanic ultraphytoplankton. J Phycol 23: $633-638$

Meixner R (1984) On a microalgal infection of Mytilus edulis. Int Counc Explor Sea Comm Meet K:30

Naidu KS (1971) Infection of the giant scallop Placopecten magellanicus from Newfoundland with an endozoic alga. J Invertebr Pathol 17:145-157

Naidu KS, South GR (1970) Occurrence of an endozoic alga in the giant scallop Placopecten magellanicus (Gmelin). Can J Zool 48:183-185

Reynolds ES (1963) The use of lead citrate at high pH as an electron-opaque stain in electron microscopy. J Cell Biol 17:208-212

Seed R (1968) Factors influencing shell shape in the mussel Mytilus edulis. J Mar Biol Assoc UK 48:561-584

Seed R, Suchanek TH (1992) Population and community ecology of Mytilus. In: Gosling E (ed) The mussel Mytilus: ecology, physiology, genetics and culture. Developments in Aquaculture and Fisheries Science, Vol 25. Elsevier, Amsterdam, p 87-170

Shaw BL, Battle HI (1957) The gross and microscopic anatomy of the digestive tract of the oyster Crassostrea virginica (Gmelin). Can J Zool 35:324-347

Stevenson RN, South GR (1974) Coccomyxa parasitica sp. nov. (Coccomyxaceae, Chlorococcales), a parasite of giant scallops in Newfoundland. Br Phycol J 9:319-329

Stevenson RN, South GR (1975) Observations on phagocytosis of Coccomyxa parasitica (Coccomyxaceae; Chlorococcales) in Placopecten magellanicus. J Invertebr Pathol 25: 307-311

Tripp MR (1969) General mechanism and principles of invertebrate immunity. In: Jackson GJ, Herman R, Sinder I (eds.) Immunity to parasitic animals, Vol 1. AppeltonCentury-Crofts, New York, p 111-128

Wiborg KF (1946) Undersøkelser over oskjellet (Modiola modiolus(L)). I. Alminnelig biologi, vekst og økonomisk betydning. Fiskeridir Skri Ser Havunders 8:1-85 (in Norwegian)

Submitted: November 5, 2003; Accepted: June 19, 2004

Proofs received from author(s): January 3, 2005 